\title{
An assessment of the livestock by-products value chains in Somaliland: The case of bones and tallow
}

\author{
Nadhem Mtimet $^{1^{*}} \mathbb{D}$, Lawrence Godiah Mugunieri ${ }^{2}$, Francis Wanyoike ${ }^{1}$, Enock Kiptoo ${ }^{3}$ and Ibrahim Gulaid ${ }^{4}$
}

\begin{abstract}
Livestock and livestock product exports are the main source of foreign currency earning in Somaliland. However, in the recent past, the growth in earnings from livestock sales has been declining against a background of increasing human population growth. Adding value to the livestock and livestock products provides an avenue for reversing the declining growth in incomes.

This report presents the findings of a study that assessed the bone and tallow value chains in Somaliland. The assessment mapped and characterised these value chains and also identified the main constraints that hinder their development.

The results showed that both value chains are short, use low-value inputs, produce relatively low-valued products and involve participants from minority groups, women and youths. This implies that they offer an opportunity for inclusive economic growth that encompasses the most vulnerable groups in the country. The final product in the tallow value chain is laundry soap, while bone trinkets are crafted from camel bones. Besides, the two value chains are complementary, such that some of the fats used to make soap are obtained from bone marrow fats, with the bones used in crafting of ornamental products. However, the two value chains have failed to exploit the various opportunities for growth due to a number of constraints that include low quality of the final products, lack of access to working and investment capital and inconsistent supply of raw materials.

Strengthening of these promising value chains will require the following interventions among others: (i) improvement of the processing skills of the value chain actors through appropriate trainings to allow the development of quality products; (ii) enhancing access to working and investment capital, through the financial institutions or donors, that will allow acquisition of the necessary new equipment to upgrade the quality and quantity of the products; and (iii) review and/or develop new business plans for the existing businesses that should include, among others, a clear sustainable growth strategy and vision.
\end{abstract}

Keywords: Bones and tallow, Value addition, SWOT, Somalia

\section{Introduction}

Livestock is the leading economic sector in Somalia where animal production and marketing (both domestic and export selling) have persisted, despite over two decades of civil war and instability (Wanyoike et al. 2015). In Somaliland (an autonomous region of Somalia located in the north, and the focus of this study), there are two main types of livestock production systems, nomadic pastoral and agro-pastoral (Marshall et al. 2016). Livestock

\footnotetext{
* Correspondence: n.mtimet@cgiar.org

${ }^{1}$ International Livestock Research Institute, Nairobi, Kenya

Full list of author information is available at the end of the article
}

production accounts for between 60 and $65 \%$ of the country's gross domestic product (GDP), employs over $70 \%$ of the population and contributes $85 \%$ of export earnings (MoNPD 2012). In 2014, a total of 3.4 million heads of livestock were exported, of which 3.1 million were sheep and goats, 0.25 million cattle and 60,000 camels (Mugunieri et al. 2016).

However, during the last few years, the export of live animals from Somaliland has been slowing, leading to the decline in national earning (SLCCIA 2015; SLCCIA 2016), and reducing pastoralists' income. Adding value to the livestock and livestock products provides an 
avenue for reversing the declining incomes and sustaining the livelihoods of pastoralists. This can be achieved by slaughtering, processing and exporting meat (chilled carcasses or packaged meat) and by investing in the transformation and processing of livestock by-products like hides and skins, and bones, tallow and horns. Previous studies have shown that slaughtering and exporting processed meat involve higher costs of refrigeration (high costs of electricity in Somaliland) and transport to the importing countries (Negassa et al. 2012). On the other hand, improving the quality of hides and skins produced and developing the value chain beyond the wet blue tanning offer a more viable investment than exports of raw wet or dried hides and skins (Wanyoike et al. 2018). The same applies to harnessing and processing of tallow, bones and horns into an array of products that include soap, cooking oil and candles (from tallow) as well as an assortment of bone trinkets (jewellery, buttons, carvings etc.) from bones and horns. Of interest, processing of bones has been shown to be an important source of employment and income for women and youths (Kinyanjui and Noor 2013).

In Somaliland, the Somaliland Meat and Development Association (SOMDA) was conceived in 2011 to take advantage of this opportunity. SOMDA is a non-profit making humanitarian local non-governmental organisation registered with the Ministry of National Planning and Development and Ministry of Livestock of Somaliland. SOMDA's aims are to play a major part in the development of livestock and livestock value addition with special emphasis on by-products and marketing of finished processed goods. The objective was to be achieved primarily through establishment and encouragement of entrepreneurship and micro-business that would produce marketable items from livestock by-products which were previously considered valueless. It was established by a professional group of local business people, whose aim was to (i) promote the livestock industry by providing opportunities through capacity-building to entrepreneurs interested in setting up businesses that will exploit the livestock and livestock by-product value addition for local as well as international markets and (ii) enable marketdriven value chain development enterprises through the use of livestock products and (iii) create income and employment for women and youth in livestock value chains in Somaliland. SOMDA's vision or desired future is the reduction of poverty for Somaliland households, especially women and youth, through their involvement in meat and by-product processing and training skills development (Cherogony 2012).

On its formation, SOMDA membership was open to any person working in the meat sector. It was started as a project funded by the Department for International Development (DFID)-UKaid and implemented by the
Food and Agriculture Organization of the United Nations (FAO). The programme included the development of bone product value chain by targeting the vulnerable groups of women and young people in the town of Hargeisa. The group received training in three main areas: bone crafts, soap and meat processing and packaging. The group sold some of the bone craft products locally and internationally (in the USA and UK) through the support of local non-governmental organisation (One Earth Future). All the processed meat was sold locally, while some of the soap was sold in eastern parts of Ethiopia as well as in local markets (Kinyanjui and Noor 2013).

The objective of this study was to undertake a detailed review of the livestock by-product value chains, focusing on livestock bones and tallow in order to document the current status of these nascent value chains with a view to identifying the main constraints that hinder their development and expansion.

\section{Study area}

SOMDA workshop is located in Hargeisa, the city capital of the self-declared, but internationally unrecognised, Republic of Somaliland. Hargeisa is situated in a mountainous area, in an enclosed valley of the Galgodon highlands, and sits at an elevation of $1334 \mathrm{~m}$ above sea level. Somaliland is one of the most difficult places in the world to do business with Hargeisa, ranking 174 out of 183 in the Doing Business Index in 2012 (RoS 2017); this is mainly due to various factors among them: remoteness, poor infrastructure, logistics, low spending power, shortage of cash etc. Although SOMDA is located in Hargeisa, the value chain products (mainly the soap derived from the tallow and fat) are sold in different towns of the country: Berbera, Burco, Borama and Tog Wajaale (Figure 1).

\section{Methods}

The study used the case study approach, focusing on SOMDA. ${ }^{1}$ The case study approach encompassed three steps. The first step entailed collecting secondary information about SOMDA and any literature on the bone and tallow value addition in the horn of Africa. The focus on SOMDA was to gather information on the type of technical training offered to the group and the company that provided the training. ${ }^{2}$

The second step involved contacting and interviewing the trainers, with a view of obtaining their perspective on the potential viability of the bone value chain in Somaliland. In addition, a request to get access to the training content was made and assented to.

The third step consisted in contacting SOMDA to schedule for focus group discussions with its members as well as conduct physical visits to their premises (in 


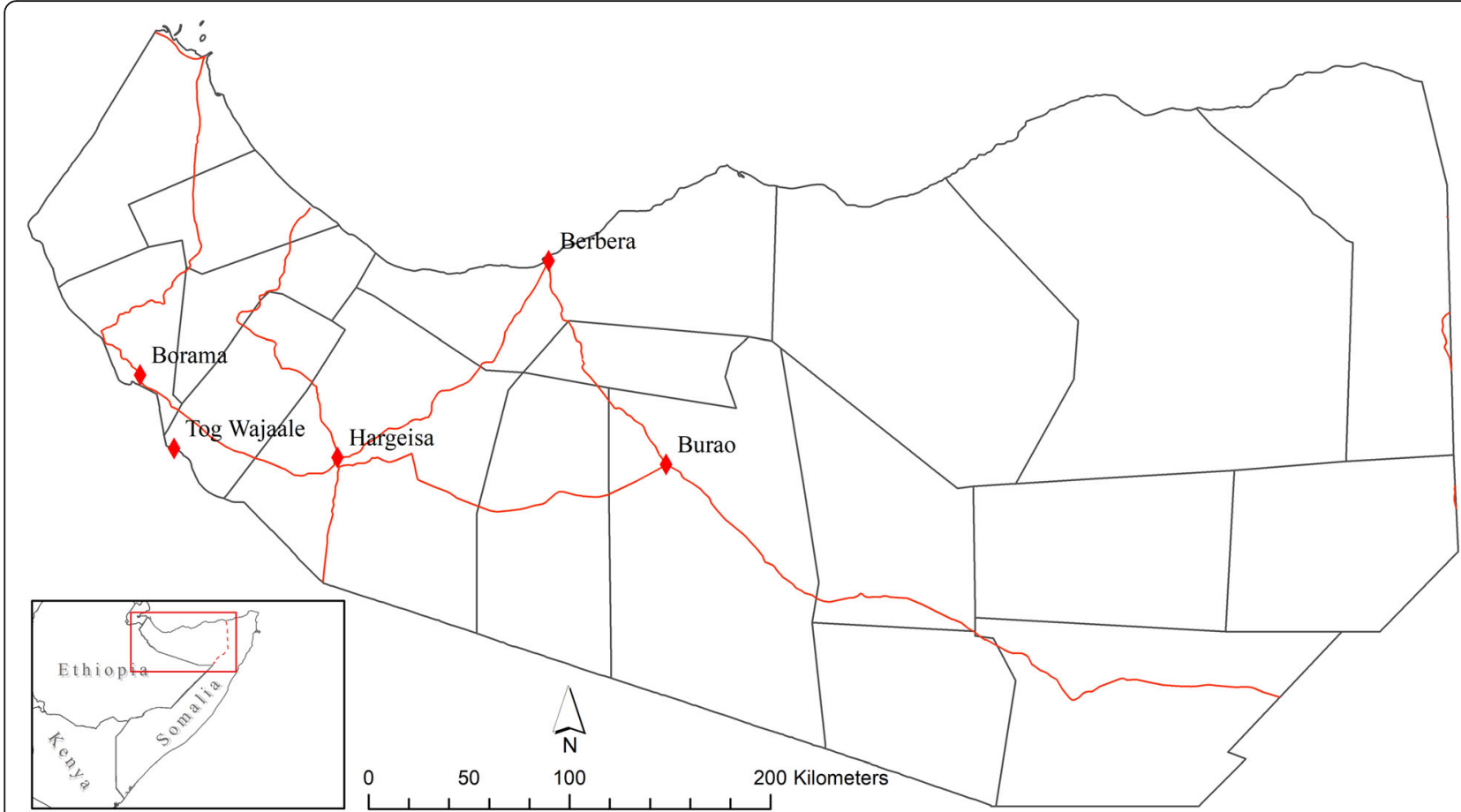

Legend

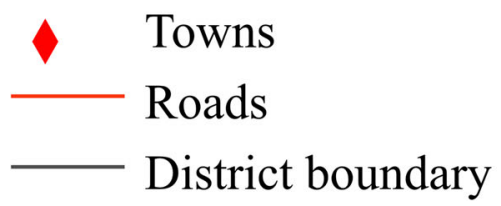

Figure 1 Map of Somaliland with the important towns receiving SOMDA's products. Legend: district boundary

Somaliland). This, it was envisaged, would provide a good understanding of the current functioning of the value chain and enable delineating constraints and opportunities within the chain. Besides contacting SOMDA, plans were put in place to select and interview some of the main raw material suppliers as well as some of the current sellers of the final products processed by SOMDA members.

\section{Results}

Mapping of the bone and tallow value chains

Information from the literature review, key informant interviews and focus group discussions revealed that the livestock bone and the tallow value chains in Somaliland are relatively short compared to other value chains. These are mainly operated by SOMDA, that serves as an umbrella organisation for self-help groups involved in cottage processing of bones and tallow; namely, the processing of soap from tallow (by Bilan soap company) and crafting of trinkets and ornaments from livestock bones (by Future Way Enterprise). ${ }^{3}$
SOMDA was said to have been involved in the establishment of these self-help groups and owns 30\% shareholding in the Bilan soap company. The groups have in the past received technical support from donor-funded projects as a way of promoting the development of cottage industries in the meat and other livestock by-product sub-sectors. An important function of SOMDA was to provide oversight to these member groups upon expiry of donor support.

It is important to note that the livestock bone and tallow value chain serves a unique niche in the livestock sector where the marginalised communities, women and youth work, and thus it contributes not only to employment creation and income generation among the vulnerable communities, but also to a safe and clean environment by making use of livestock by-products that often pile up as landfill.

The value chains start with the collection of fresh bones from slaughterhouses and butchers and their delivery to the SOMDA workshop (Figure 2). From here, the first step is to remove fats (both from outside and 


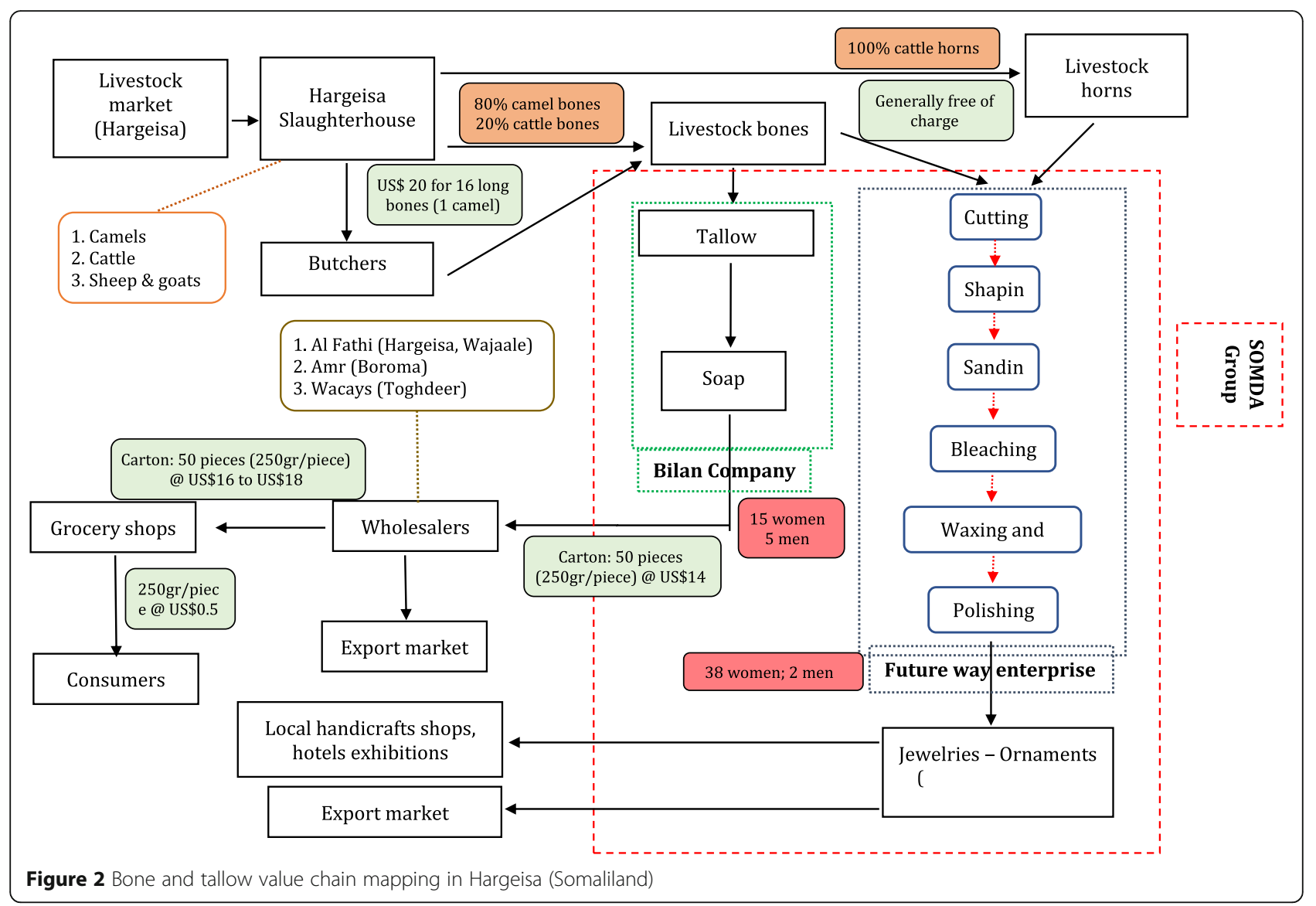

within the bone marrow) which is used to produce soap. The soap is sold to wholesalers and grocery shops in Hargeisa and other regions in Somaliland.

The bones free from fat are then boiled in water and detergent and cleaned. This then undergoes a six-step processing involving cutting, shaping, sanding, bleaching, waxing and dying, and polishing (see Figure 2). In order to effectively undertake these tasks, there is a need to acquire specific skills and procure appropriate equipment like sanding wheels, tables, drilling machines, sand paper, among others.

The final products include an assortment of ornaments and trinkets including but not limited to napkin holders, key holders, flower vases, candle holders, earrings and necklaces. The products are mainly sold to local handicraft shops and hotels in Hargeisa. It was observed that if the quality is improved, there exists potential for serving export markets.

\section{Evolution of the value chains}

The bone and tallow value chains were born out of a donor-funded initiative aimed at spurring the development of cottage industry within the livestock sector in Somaliland. At the onset, in 2011, SOMDA members were taken through training sessions on bone crafting and soap processing from tallow and fats. They were also offered tips on how to fabricate some of the elementary equipment used in processing of the bone and horn handicraft products. It was noted that the group did not receive training on how to develop high-quality finished products and on export markets and their requirements on quality bone trinkets.

Overall, the trained group comprised of 30 participants who were segmented in two groups: one, of 15 persons received training on bone crafting, and the remainder (mainly women) received training on soap making. Because of limited resources, training on horn crafting was not offered. ${ }^{4}$ These trainings facilitated the establishment of businesses in bone crafting and soap processing.

It was noted that camel bones were the best inputs since they were in abundance from the Hargeisa slaughterhouse. They were also longer and had wider girth compared to cattle or shoat bones, which allowed for production of a wider range of better products. Some of the products reported to have been developed by the group are given in Figure 3.

Following the training, all the processing of the products was manual, which limited bulk production of the goods, particularly for soaps. Besides, the inability to 


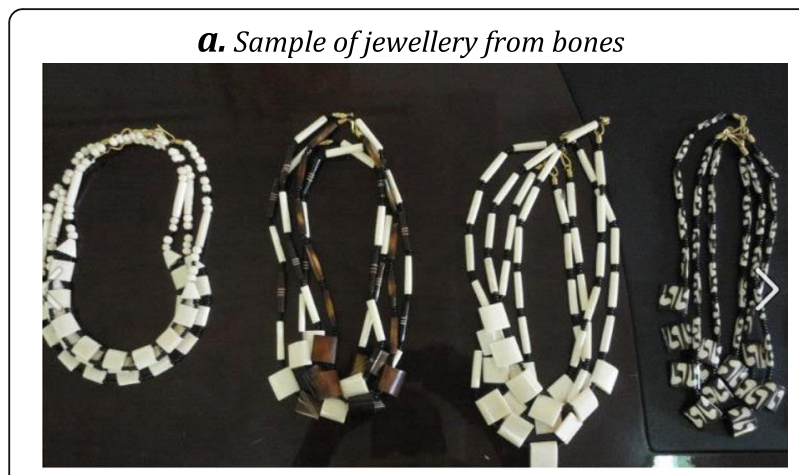

b. Group members assembling jewellery

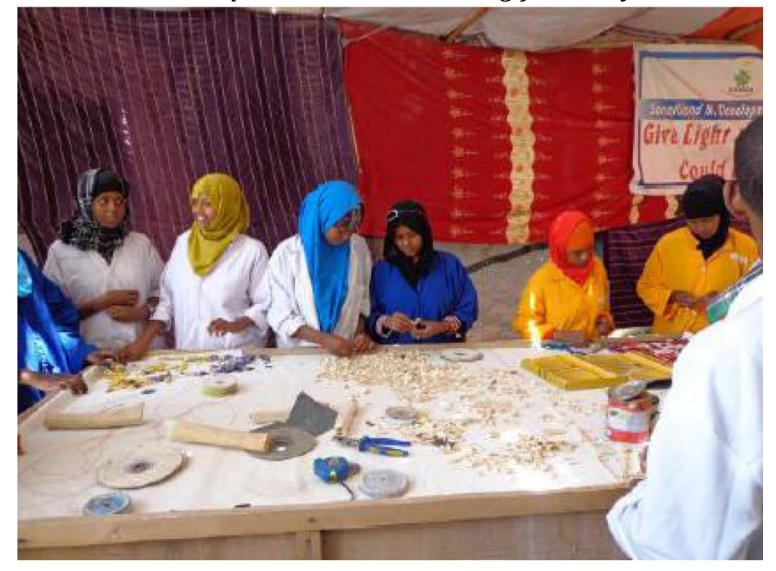

C. Bar soap produced from tallow

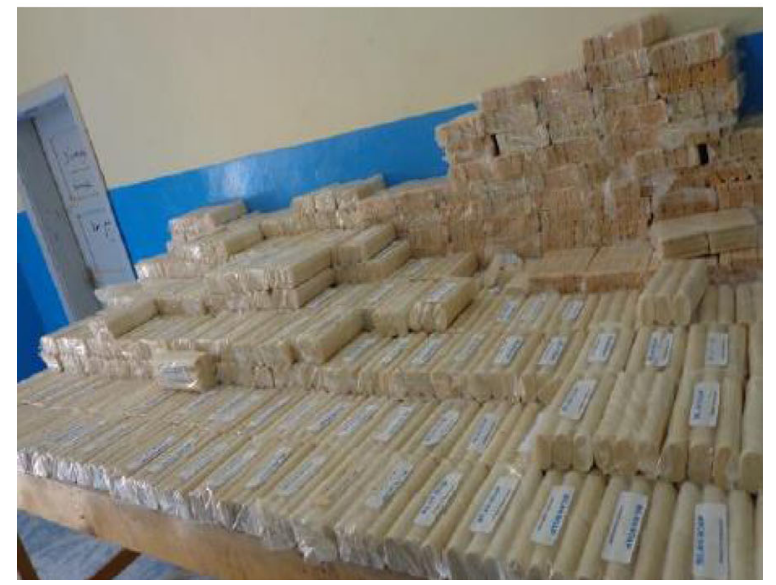

Figure 3 Display of some of the products reported to have been processed by SOMDA from bones

penetrate the export market for bone trinkets and ornaments meant that there were limited outlets for these products due to the very thin nature of the local market.

\section{Supply of inputs for the value chains}

Visits were made to the Hargeisa slaughterhouse and information collected on the availability of inputs for the livestock value chain, which revealed:
- 1200 heads of sheep and goats are slaughtered per day during the low season, and this could reach up to 3000 heads/day during the Eid religious times (peak period);

- 60 to 65 heads of cattle per day are slaughtered, and a maximum of 130 heads during the peak season has also been recorded; and

- 130 heads/day of camels are slaughtered within the facility

On Fridays, the total number of slaughtered animals often reaches around 2000. These numbers indicate the availability of 'raw' material for the bone and horn value chain providing opportunities for growth.

\section{Soap processing from tallow}

Soap processing from bone marrow fat is undertaken by a formally registered group of men and women. ${ }^{5}$ The group was registered in 2014 with both the Ministry of Trade and the Office of the Attorney General with a total membership of 40 including 35 women and 5 men. The group engaged in soap processing from inception until December 2016 when it stopped due to a number of structural obstacles.

The group produced and sold soap to wholesaling companies across Somaliland. ${ }^{6}$ The business plan developed for the group indicated a steady increase of the production from 80 tons in 2014, to 150 tons in 2015, to 300 tons in 2017. During the focus group discussion, it was noted that during the peak demand period, the group was able to produce 500 cartons in 3 days (approximately 2 tons/day) which exceeded the projected targeted production for 2017.

\section{Constraints faced by the soap processing unit}

Despite the elevated growth in production, the group faced some structural constraints that partly contributed to its collapse in 2016. These included:

\section{(a) Problems of quality of final products}

The soap produced by the group contained high amounts of glycerine. Apparently, extraction of glycerine had not been included in the training package offered to the group. The non-stabilised soap thus provided a good medium for fungal growth particularly during the cold season, which turned it black (Figure 4). This led to significant losses. In one such major incidence, the group was faced with a situation where it had to take back the spoilt consignment of around 12,000 cartons ${ }^{7}$ (value of United States dollars (US\$) 84,000) and compensate its buyers as agreed in the supply contract.

Although the group subsequently received some training on glycerine extraction from FAO and were able to 

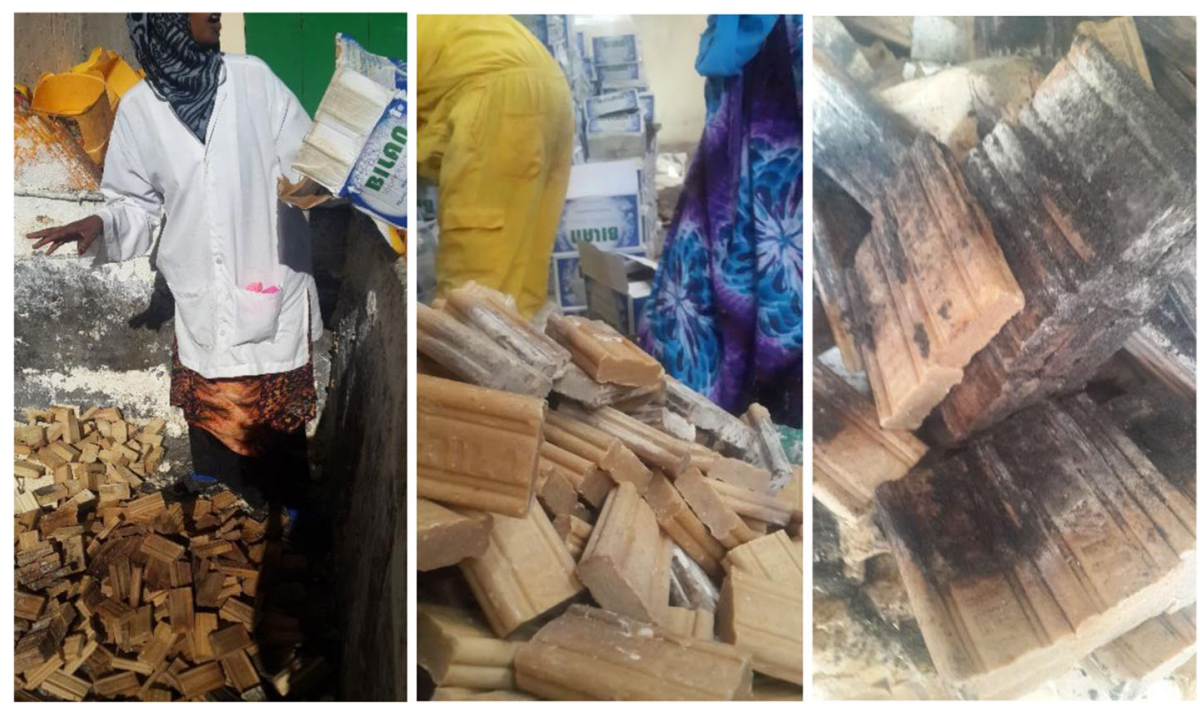

Figure 4 Photos of the returned spoiled soap due to fungal growth

progressively improve their product quality to a level acceptable by the buyer, losses emanating from compensation for the spoilt consignment that had been supplied earlier became burdensome to the group. For every 100 cartons of the improved quality product they supplied, the group was supposed to give an additional 10 cartons as compensation until the entire quantity that got spoilt was fully compensated.

Part of the spoilt soap consignment that had already been distributed to retailers had to be recalled at the expense of the group, further compounding its losses. Additional costs were also incurred in changing the packaging as a way of rebranding. The spoilt soap was recycled and mixed with the raw materials to produced new soap using a technology learned from an Ethiopian company that had gone through a similar experience. Mixing of animal fat with other imported non-edible oils was also noted to have resulted in lower production costs.

\section{(b) Limited options for business financing}

The group observed that while the financial capital needed to make bulk production was high, they were unable to access loans from local financial institutions. On many occasions, they had to suspend production until they got paid by their distributors. It was noted that lending conditions in the main local banks were difficult to meet, as they failed to obtain a guarantor to endorse and back their loan request. In addition, loan repayment periods were restricted to one year and subject to a high interest rate.

(c) Escalating cost of raw material
During the 2016 drought, many households resorted to using animal fat as a substitute for vegetable fat. This led to severe shortage of the commodity and significant increase in price from approximately US\$20 per $20 \mathrm{l}$ of fat to about US\$70 to US\$80, making the use of animal fat in soap making economically unviable.

\section{(d) Competition from imported products}

It was noted that the final product faced high competition with imported soaps from Thailand, India and China. Even though both locally produced soap and the imported products were priced at the same level, the latter tended to be bigger (higher weight) and lasted longer.

\section{(e) Environmental concerns}

Production was done in a residential area causing pollution (smell and dust) leading to protests from residents for the production premises to be relocated.

\section{Costing the activities of the soap processing unit}

The soap processing group used to procure camel bones with the bone marrow from a single camel (about 16 long bones) at about US $\$ 20$. The steps leading to production of soap from such bones included:

- Cleaning

- Cutting

- Removal of the bone marrow

- Mixing and measuring fat and caustic soda solution 
- Adding colour and perfume (optional depending on the target market) and stirring of mixture for about an hour before moulding

- Pouring soap mixture into fabricated moulds (cold process of soap making). However, before closure, the group had acquired soap plodder machine which allows the production of soap in a continuous way (hot process of soap making)

- Manual cutting of the soap bars followed by sun drying

Based on the business plan developed for soap processing by the group, the estimated production cost per ton in 2014 was US\$1932. This was expected to decrease in subsequent years as production increased to about US\$568/ton in 2017. These unit costs, income and profits are summarised in Table 1.

Each soap bar weighed $250 \mathrm{~g}$ with a wholesale price of US $\$ 0.28$. The soaps were packed in carton boxes of 50 bars each. All the three wholesalers had formal supply contracts with the soap processor and more often than not made payments upfront as a gesture of supporting the nascent processing business. Most of the soap was sold in the local market but there were occasional exports by the wholesalers to Ethiopia. Wholesalers' selling prices to the retailers ranged between US $\$ 16$ and US\$18 per carton of 50 pieces. Consumers were buying a bar about US $\$ 0.5$ (between 2,500 Somaliland Shilling (SLS) and 3,000 SLS) which translated to approximately US\$25 per carton.

\section{The crafting of bone trinkets}

The bone trinkets crafting group (Future Way Enterprise) was formed in 2013 and was registered with the Ministries of Trade and Livestock, as well as the Attorney General's office. It had 40 members, of whom 38 were women and two men. It crafted an assortment of trinkets including earrings, necklaces, rings and bangles.

The bone crafts produced were mainly sold in the local market exhibitions mall and in hotels frequented by foreign nationals. However, it was observed that in one instance, some of the products were exported to the

Table 1 Projected profitability of the soap processing business, 2014-2017

\begin{tabular}{llll}
\hline Year & 2014 & 2015 & 2017 \\
\hline Projected production (tons) & 80.00 & 150.00 & 300.00 \\
Gross income (US\$) & $144,000.00$ & $220,000.00$ & $270,000.00$ \\
Income/ton(US\$) & $1,800.00$ & $1,466.67$ & 900.00 \\
Total costs (US\$) & $154,564.00$ & $199,420.00$ & $170,520.00$ \\
Cost/ton (US\$) & $1,932.05$ & $1,329.47$ & 568.40 \\
Profit/ton (US\$) & -132.05 & 137.20 & 331.60 \\
\hline
\end{tabular}

Source: Bilan business plan 2014-2017 (unpublished document) and own estimations
USA and the UK, through support of an American foundation called One Earth through its programme Shuraako. ${ }^{8}$ Export sales to both countries were however not sustained as the importers complained about quality and insisted that they needed finished products.

It was noted during the focus group discussion that even though the potential customers in Somaliland and particularly women are many, very few made purchases ostensibly because the product was not well finished. The women in Somaliland spend substantially on jewellery ${ }^{9}$ most of which are imported from China and other countries. Prices of non-gold jewellery (bulokati) in the local market stand at about US\$5 per earring and US\$20 to US $\$ 50$ per necklace. Potential local buyers of bone crafts made by the group who could act as outlets for buyers in Somaliland were identified as jewellery stores and supermarkets. The group ceased operation in 2015 due to lack of market ostensibly due to poor quality of final products arising from lack of skills and equipment in final finishing, polishing and colouring of final products. Of concern, the final products were not of uniform shape and size since the group lacked a machine for sizing $^{10}$ (fixer to produce same-sized beads) whose estimated cost is about US\$15,000.

\section{Options for revitalising the bone and tallow value chains in Somaliland}

The crafting of bone trinkets and processing of soap from bones and tallow played an important role in the Somaliland economy in two ways. First, it was a source of employment for women and youths, and more importantly, those from marginalised communities. Second, since it used inputs that would otherwise accumulate in landfills, they contributed towards maintaining a clean and healthy environment (Kinyanjui and Noor 2013). Therefore, the closure of the two start-up businesses has had negative consequences at both household and national levels within the Somaliland economy.

A Strength Weaknesses Opportunities and Threats (SWOT) analysis was thus carried out to identify the strengths and weaknesses of the soap processing and bone crafting ventures, as well as the threat and opportunities they faced with a view of delineating key bottlenecks to be redressed in revitalising the businesses. This analysis was undertaken with the understanding that whereas strengths and weaknesses are internal to the businesses and would be easier to redress, opportunities and threats were external factors and thus would require a multi-sectoral intervention approach.

The analysis highlighted a number of strengths for both enterprises as well as the weaknesses faced. Besides, potential opportunities were identified, which when exploited, could significantly contribute to strengthening of the businesses. These are described below: 
(a) Business strengths

- There exist sufficient supplies of raw materials (livestock bones and tallow) in the local market and at a short distance. The development of export slaughterhouses currently taking place will also increase the availability of these materials.

- The soap production process largely relies on natural inputs, viz. camel tallow and natural fragrance and colourants. This is preferred by consumers and has potential to attract more buyers if final products are standardised and certified.

- There exists good-will from other value chain actors within the market - the soap business has reliable wholesalers who collect and deliver products to retail outlets located all over Somaliland. More often than not, the wholesalers pay upfront, thus relieving the business from cash flow problems. This marketing model also reduces overall marketing costs.

- The vertical integration between soap processing and bone crafting businesses is designed to reduce the overall operational costs of the two ventures. The bones, which are waste from soap processing, are an input in the handicraft company.

(b) Weaknesses

- There was lack of a well-formulated business plans for the two enterprises. The business plan for soap processing (Bilan business plan) is not well developed and does not include all required detailed information about the production costs, the need of cash flow and the marketing strategy to follow. On the other hand, the bone crafting venture (Future Way) does not have a business plan.

- There was lack of growth-oriented marketing strategy for the bone crafting business, while in the soap business, there was reliance on only three wholesale outlets which posed a potential risk to the business.

- The human resource involved in processing of soap and crafting of trinkets did not have sufficient skills to produce high-quality products that can withstand competition from international markets.

- The businesses had limited options for financing their growth, particularly in the acquisition of equipment and machinery. This curtailed the capacity of the ventures to produce products that are uniform, standardised and of consistent quality. Most importantly, the soap business was unable to respond to occasional upsurge in demand, as they had constraints in production.
- Production workshops were located in a residential area with increasing pressure from residents to relocate due to pollution.

(c) Opportunities

- The businesses exhibit positive environmental impacts through conversion of bones and horn waste that would have ended up in landfills instead into value-added products. This act has increased buyers' interest and attracted support from the Government and other development partners.

- Both value chains are short (few actors are involved) which offers opportunities for timely delivery of raw materials and lower transaction costs. This will more likely translate to lower prices of final products.

- The growth of trade in processed meat products locally and for the exports which ensures raw material availability.

- The availability of mobile phone and social media communications which among other things facilitate communication and information sharing, and enable payment.

- Increasing demand for animal feed provides an option for further diversification of the business by inclusion of bone meal as part of the product portfolio.

- The establishment of the national standards body, the Somaliland Quality Control Commission (SQCC), provides an opportunity to develop and promote product and process standards that will lead to production of standardised products of better quality leading to increased market opportunities.

(d) Threats

- More often than not, the main input used in soap processing (tallow) becomes a key source of food for the majority of the low-income households in the Somali ecosystem during periods of stress (like drought). This alternative and competing use of the input leads to reduction in supplies and increase in price and in the process exposes the company to cyclic shocks. Due to on-going changes in climate and the increasing frequency of extreme climatic events (like droughts), such supply shocks will most likely increase in frequency and intensity.

- The businesses face competition from imported products (soap and jewels) particularly from Asia, China and India.

- The ease of entry into the bone crafting and soap processing businesses due to low entry-barriers provides a potential risk of rapid change in market structure and loss of market share. 


\section{Discussion and conclusions}

The bone and tallow value chains in Somaliland are short, use low-value inputs, produce relatively lowvalued products and involve participants from minority pastoralist groups, women and youths. These value chains offer an opportunity for inclusive economic growth that encompasses the most vulnerable groups in Somaliland, and directly and indirectly generate additional revenues for the pastoralists. The value chains have in the past directly employed more than 150 persons, sustaining thus around 1,000 persons (average of six persons per household), and in the case of the tallow/soap value chain, it was worth US\$150,000 income to severely disadvantaged groups living in both urban and pastoral areas.

However, like most pro-poor value chain in developing countries (see UNIDO 2011), the nascent value chains in Somaliland have faced a myriad of problems that have continued to threaten their mere existence.

Findings of this study have shown that the bone and tallow value chains face many constraints that affect their performance and limit participation of the poor in markets (Ravallion 2007). As outlined by Poulton et al. (2006), some of these constraints include low monetary incomes for most market actors, a poorly developed monetary economy with a narrow base and input and output markets which are relatively 'thin' and prone to large seasonal variability in demand and supply. Strengthening of these value chains therefore require deliberate and targeted interventions in order to overcome these constraints that force the poor to perpetually operate in low equilibrium traps.

It has however been argued that undertaking investments that are supportive of pro-poor value chains in most sub-Saharan countries is fraught with high risks of transaction failure and hence high transaction costs are incurred in obtaining protection against such risk (Poulton et al. 2006). Yumkella et al. (2011) have also shown that the transformation of agricultural raw materials into higher value products does depend not only on investments in new agro-food technologies but also on value chain systems and capacities that are put in place to reduce transaction costs.

These transaction risks (and costs) have two components that are applicable to the bone and tallow value chains in Somaliland. The first set encompasses the 'co-ordination risks', i.e. the risk of an investment failing as a result of the absence of complementary investments by other players in a supply chain. Such missing but important complementary investments in the case of the bone and tallow value chains in Somaliland include absence of product and process standards to guide production of quality and consistent products, weak finance markets to promote upgrading of the value chains and lack of protection from dumping of low-quality competing imports. Kelly (2012) indicated that access constraints to finance, inputs and technical assistance is nonetheless endemic across all smallholder-based agriculture commodities in developing countries, and without improved access, it is difficult for small farmers to compete in modern markets.

The second class of transaction risk is the 'opportunism risks', i.e. the risk which arises when another contracting party, with monopsonistic or monopolistic control over a complementary investment or service, removes, or threatens to remove, it from the supply chain after a player has made an investment that depends upon it. The findings of this study have shown that the bone and tallow value chains failed to grow and modernise due to limited options for business financing, and on several occasions, production had to be suspended until payments were received from distributors.

Based on the preceding analysis and borrowing from lessons learnt in promoting pro-poor value chains in sub-Saharan Africa, three broad functional intervention types required to revive the bone and tallow value chains in Somaliland can be identified, namely (i) improved value chain co-ordination, (ii) pump priming investment and (iii) threshold shifting (Poulton et al. 2006).

Value chain co-ordination should entail the development of an effective system to support co-ordinated, complementary decision-making by different players along the value chain. At the moment, most of the actors are faced by a myriad of constraints that have limited their capacity to form decisions supportive of the value chain development. For example, the business operators have shown limited skills to develop products of good quality responsive to market needs and have in past incurred huge losses arising from production of sub-standard products. This issue seems endemic to Sub-Saharan Africa. For instance, Coates et al. (2011) have also indicated that in Kenya, agribusiness is generally weak and is characterised by low capitalisation and a lack of professional and technical management skills. The authors advocate for well-funded and well-organised producer organisations, which are a vital component in linking small farmers with other stakeholders and the rest of the economy.

On the other hand, the Ministry of Commerce has failed to formulate policies that would shield the nascent soap processing unit from unfair competition from dumped imports. Last but not the least, the new standard body (SQCC) lacks sufficient technical capacity to guide the soap and crafts businesses in the process of developing product standards consistent to those traded in international markets. In this regard, it is clear that a system relying exclusively on market mechanisms will not be able to provide the co-ordination necessary to cross substantial thresholds. In the past, such co-ordination has effectively 
been played by international organisations due to the existing capacity gaps within the public sector.

The second intervention, 'pump priming investment,' should seek to provide a higher investment base along the value chain. In essence, this should be donor investments (due to low capacity of the Somali public sector) that will move the level of investment beyond a point that the businesses will withstand the identified structural constraints. In doing so, it will be important to ensure that the pump priming is well-targeted to take advantage of the identified potential growth opportunities, but it is also large enough and continues long enough to cause major and permanent shifts in expectations and structural relations within the supply chain.

Ponte (2011) indicated that donor support is often required to help smallholders adapt to new situations or to promote organisational mechanisms that can help them to re-enter a value chain. According to Staatz (2011), a top priority is to create conditions in which local communities, local governments, non-governmental organisations (NGOs) and the private sector (including producers themselves) mobilise their own resources to invest in agribusiness.

The third form of intervention, 'threshold shifting, should essentially be achieved by technical change (which increases the marginal productivity of investment) or by decreases in output price. Phrased in another way, this will entail investments in areas that will resolve the identified weaknesses in the businesses. Thus, the two businesses will need to invest in capacity to upgrade production process by investing in modern processing equipment that will enable them to improve quality and quantity of products and by extension lower price of final products. As mentioned by Wohlmuth (2011), agro-industrial development policies in Africa will - in order to realise sustainable successes - also depend on substantially increased donor support for stimulating innovation directly at the enterprise level.

\section{Endnotes}

${ }^{1}$ To our knowledge, SOMDA is the only group/association in Somaliland which has received training on and is involved in the bone and horn value addition activities. There are other groups mainly in Puntland which also received similar type of training.

${ }^{2}$ The training was offered by Bemos Crafts Developers, a company based in Nairobi.

${ }^{3}$ SOMDA is also involved in the processing of fresh meat into dried meat to enhance its shelf life (through Masno Company) - dried meat produced is also known as Muqmad in the Somali language.

${ }^{4}$ Sheep and goat horns could be transformed into bottle-openers, key-holders, or pen-holders

${ }^{5}$ Bilan soap enterprises.
${ }^{6}$ There were three companies sub-contracted by the group to distribute its products. These were Al Fathi in Hargeisa and Wajaale, Aamr in Borama, and Wacays in Togdheer

${ }^{7}$ The cartons distributed and collected were of 50 pieces each, and the price of each carton was US\$ 7. Al Fathi was given 4,000 cartons of soap that was spoiled, Aamr 5,000 cartons, and Waics 3,000 cartons

${ }^{8}$ Shuraako is a programme of One Earth Future (OEF), operating throughout Somalia. Shuraako, which means 'partnership' in Somali, produces economically beneficial relationships that connect micro-, small- and mediumsized enterprises (MSMEs) to capital to catalyse job creation. This in turn contributes to a more resilient and peaceful Somalia. Shuraako seeks to foster a thriving business sector in Somalia to encourage economic development (http://shuraako.org/about-us).

${ }^{9}$ The women especially try to match the colour of their jewellery worn with the colour of their clothes.

${ }^{10}$ Cutting by hand produces different sizes of beads.

\section{Abbreviations}

DFID: Department for International Development; FAO: Food and Agriculture Organization of the United Nations; ILRI: International Livestock Research Institute; MSMEs: Micro-, small- and medium-sized enterprises; OEF : One Earth Future; SLCCIA: Somaliland Chamber of Commerce, Industry and Agriculture; SLS: Somaliland Shilling; SOMDA: Somaliland Meat and Development Association; SQCC: Somaliland Quality Control Commission; SWOT: Strengths Weaknesses Opportunities Threats; UNIDO: United Nations Industrial Development Organization; US\$̦: United States dollar

\section{Funding}

We acknowledge and are grateful to the Danish International Development Agency (DANIDA) for funding this study trough the project 'Provision of Livestock Investment and Vocational Education Programme' (LIVE) in Somalia, contract no. DC:3199.

\section{Authors' contributions}

NM participated in the development of the checklist, the data collection and analysis and in the writing of the paper. LMG participated in the design of the checklist and in the analysis and writing of the paper. FW participated in the design of the checklist, the data collection, the analysis and writing of the paper. EK participated in the analysis and writing of the paper. IG participated in the data collection and writing of the paper. All authors read and approved the final manuscript.

\section{Competing interests}

The authors declare that they have no competing interests.

\section{Publisher's Note}

Springer Nature remains neutral with regard to jurisdictional claims in published maps and institutional affiliations.

\section{Author details}

${ }^{1}$ International Livestock Research Institute, Nairobi, Kenya. ${ }^{2}$ Terra Nuova NGO, Nairobi, Kenya. ${ }^{3}$ IGAD Sheikh Technical Veterinary School, Sheikh, Somalia. ${ }^{4}$ Terra Nuova NGO, Hargeisa, Somalia.

Received: 28 May 2018 Accepted: 17 July 2018

Published online: 28 August 2018

\section{References}

Cherogony, M. 2012. Assessment on the current and potential supply and demand, marketing opportunities and consumer preferences for livestock value added 
products. Sustainable Employment and Economic Development (SEED) project, 36. Assessment Report. Development Outcomes Limited.

Coates, M., R. Kitchen, G. Kebbell, C. Vignon, C. Guillemain, and R. Hofmeister. 2011. Financing agricultural value chains in Africa. Focus on dairy and mangos in Kenya. Bonn: Deutsche Gesellschaft für Internationale Zusammenarbeit (GIZ) $\mathrm{GmbH}$.

Kelly, S. 2012. Smallholder business models for agribusiness-led development. Good practice and policy guidance. Rome: Food and Agriculture Organization of the United Nations.

Kinyanjui, W., and S.M. Noor. 2013. From waste to employment opportunities and wealth creation: A case study of utilization of livestock by-products in Hargeisa, Somaliland. Food and Nutrition Sciences 4: 1287-1292.

Marshall, K., N. Mtimet, F. Wanyoike, N. Ndiwa, H. Ghebremariam, L. Mugunieri and R. Costagli. 2016. Traditional livestock breeding practices of men and women Somali pastoralists: Trait preferences and selection of breeding animals. Journal of Animal Breeding and Genetics 133: 534-547.

MoNPD: Ministry of National Planning and Development. 2012. Bulletin of statistics, 4, 4. Hargeisa Somaliland Also available at: http://probeinternational. org/library/wp-content/uploads/2012/05/volume-four1.pdf.

Mugunieri, G.L., Mtimet, N., Enock, K., Costagli, R., Gulaid, I. 2016. Saudi Arabia endmarket requirements and the implications for Somaliland livestock exports. ILRI research report 40. Nairobi: International Livestock Research Institute (ILRI).

Negassa, A., Baker, D., Mugunieri, L., Costagli, R., Wanyoike, F., Abdulle, M.H., Omore, A. 2012. The Somali chilled meat value chain: Structure, operation, profitability and opportunities to improve the competitiveness of Somalia's chilled meat export trade. ILRI research report 32. Nairobi: International Livestock Research Institute (ILRI).

Ponte, S. 2011. Upgrading value chains. In Agribusiness for Africa's prosperity, ed. K Yumkella, P. Kormawa, T. Roepstorff, and A. Hawkins, 87-134. Vienna: United Nations Industrial Development Organization (UNIDO).

Poulton, C., J. Kydd, and A. Dorward. 2006. Overcoming market constraints on pro-poor agricultural growth in sub-Saharan Africa. Development Policy Review 24 (3): 243-277.

Ravallion, M. 2007. Economic growth and poverty reduction: Do poor countries need to worry about inequality? 2020 vision brief. Washington, DC: International Food Policy Research Institute (IFPRI).

RoS: Republic of Somaliland. 2017. The National Development Plan II: 2017-2021. Ministry of National Planning and Development.

SLCCIA: Somaliland Chamber of Commerce, Industry and Agriculture. 2015. Yearly report for the period: 01-01-15 - 31-12-15. Hargeisa: SLCCIA.

SLCCIA: Somaliland Chamber of Commerce, Industry and Agriculture. 2016. Yearly report for the period: 01-01-16 - 31-12-16. Hargeisa: SLCCIA.

Staatz, J. 2011. Enhancing agricultural productivity. In Agribusiness for Africa's prosperity, ed. K. Yumkella, P. Kormawa, T. Roepstorff, and A. Hawkins, 58-86. Vienna: United Nations Industrial Development Organization (UNIDO).

UNIDO: United Nations Industrial Development Organization. 2011. Pro-poor Value Chain Development: 25 guiding questions for designing and implementing agroindustry projects. In United Nations Industrial Development Organization (UNIDO). Vienna: Austria.

Wanyoike, F. N. Mtimet, N. Ndiwa, K. Marshall, L. Godiah, and A. Warsame. 2015. Knowledge of livestock grading and market participation among small ruminant producers in northern Somalia. East African Agricultural and Forestry Journal 81 (1): 64-70

Wanyoike, F., Mugunieri L.G., Mtimet N., Enock K., Gulaid I. 2018. An analysis of the hides and skins value chain in Somaliland. ILRI Research Report 50 . Nairobi: International Livestock Research Institute (ILRI).

Wohlmuth, K. 2011. Strengthening technological effort and innovation capabilities. In Agribusiness for Africa's prosperity, ed. K. Yumkella, P. Kormawa, T. Roepstorff, and A. Hawkins, 165-199. Vienna: United Nations Industrial Development Organization (UNIDO).

Yumkella, K., P. Kormawa, T. Roepstorff, and A. Hawkins. (eds.) 2011. Agribusiness for Africa's prosperity. United Nations Industrial Development Organization (UNIDO). Vienna.

\section{Submit your manuscript to a SpringerOpen ${ }^{\circ}$ journal and benefit from:}

- Convenient online submission

- Rigorous peer review

- Open access: articles freely available online

- High visibility within the field

- Retaining the copyright to your article

Submit your next manuscript at $\boldsymbol{\nabla}$ springeropen.com 